\title{
Do wages reflect labor productivity? The case of Belgian regions
}

\author{
Jozef Konings $^{1}$ and Luca Marcolin ${ }^{2 *}$
}

\author{
* Correspondence: \\ luca.marcolin@kuleuven.be \\ ${ }^{2}$ Katholieke Universiteit Leuven, CES \\ \& VIVES, Naamsestraat 61, 3000 \\ Leuven, Belgium \\ Full list of author information is \\ available at the end of the article
}

\begin{abstract}
We simultaneously estimate a wage and a labor productivity equation where we include regional dummies as explanatory variables. We find that the wage-productivity gap reached $11 \%$ for Brussels and $4.2 \%$ for Wallonia in the years 2005-2012. This was driven by the negative performance in labor productivity of firms in these regions relative to Flanders, which more than compensated for the advantage in average salary cost they enjoyed. These results are coherent with the existence at the regional level of institutional barriers to the firm-level adjustment of wages to labor productivity.

JEL codes: J24; J31; J5; R23
\end{abstract}

\section{Introduction}

Classic economic theory applied to the labor market assumes that markets are perfectly informed and able to allocate workers in open vacancies. These workers are paid a salary equal to their marginal product of labor, since labor supply and demand are both satisfied. In the real world, however, this condition might not hold: many market frictions exist which are triggered by imperfect information and institutional factors such as employment protection, unemployment benefits, collective bargaining, minimum wages and taxation. Manning (2011) widely discusses different models in which imperfect competition in the labor market creates a wedge between average productivity and average worker compensation, thus permitting the employer to appropriate part of the surplus of the matching between labor supply and demand. The persistently high unemployment rates plaguing the Western World and Europe in particular in the aftermath of the Great Recession suggest that wage rigidity combined with falling productivity may be an important channel causing increasing unemployment. Belgium is no exception, with $7.6 \%$ national unemployment rate in 2012 averaging over the $17.5 \%$ unemployment rate of Brussels, the $4.6 \%$ rate of Flanders and the $10.2 \%$ rate of Wallonia (source: Eurostat).

The current study searches for an economic rationale for these persistent differences in unemployment across regions, and it does so by analyzing deviations in the evolution of wages and labor productivity for Brussels, Flanders and Wallonia. We will therefore estimate simultaneously a labor productivity function and a wage equation on Belgian firm level data, where we include indicators for the regional location of the firm as main explanatory variable. In this way, we also analyze the relative competitiveness of Belgian regions. Labor productivity growth is considered a key indicator to

(C) 2014 Konings and Marcolin; licensee Springer. This is an Open Access article distributed under the terms of the Creative Commons Attribution License (http://creativecommons.org/licenses/by/2.0), which permits unrestricted use, distribution, and reproduction in any medium, provided the original work is properly cited. 
assess regional competitiveness, together with the increase in labor utilization and cost. These metrics are fundamental to the determination of the gains in living standards of regions over time, therefore they hold a prominent position on the policy makers' agenda at the European level. This ambition can be found in the EU2020 agenda, where it is stated that Europe needs "a strategy to turn the EU into a smart, sustainable and inclusive economy delivering high levels of employment, productivity and social cohesion". Shortly below it is reported that the EU2020 strategy aims at "empowering people through the acquisition of new skills to enable our current and future workforce to adapt to new conditions and potential career shifts, reduce unemployment and raise labor productivity".

Our results present evidence of stronger deviations between labor productivity and wages in Wallonia and Brussels relative to Flanders. While the average labor costs of firms in Wallonia and Brussels are lower than in Flanders, the gap between average labor costs and labor productivity is even larger. As a consequence, firms in Wallonia or Brussels have a competitive disadvantage compared to Flanders, although the gap seems to be narrowing in the last year for Brussels.

The study is organized as follows: the first paragraph shortly describes the labor market in Belgium, while the second provides a literature review on the link between productivity, wages and regional unemployment differentials. A third paragraph follows commenting on the empirical methodology and the literature which proposed it. The fourth paragraph presents the data we exploit, the fifth the results of the econometric analysis. The conclusion follows.

\section{The institutional context}

Although unemployment in Belgium seems to be on a decreasing pattern down from the 2011 peak, mismatches between vacancies and available workforce have not substantially decreased in 2012 compared to 2007: almost half of the long term unemployed are still low or medium skilled, while $80 \%$ of vacancies search skilled workers (Zimmer 2012). This happens despite Belgium being among the highest spenders for labor market policies (LMP) in Europe: (latest available data, source: Eurostat 2010) it invested more than 3.7\% of GDP in LMPs, ranking third in Europe after Spain and Denmark. It also ranked fourth from the top for expenditure in labor market services and sixth for out-of-work income maintenance and support. Such malfunctioning of Belgian labor market is also stressed in the OECD (2013) Economic Survey for Belgium, which states that "longstanding structural labor market problems remain, such as high structural unemployment, low employment rates for younger and older workers and for low-skilled and migrants, and large labor market mismatches".

Many have pointed to the role of labor market institutions as fundamental contributing factors: the OECD (2011) Economic Survey for Belgium, for instance, reports that "coordinating policies to secure a smoother transition [from the crisis labor market equilibrium] is difficult, as the communities are responsible for education, the regions for employment and professional training, and the federal government for labor legislation, collective agreements and social security"1. Among these institutions, the OECD (2013) Economic Survey for Belgium points in particular at wage setting practices, where it states that "the highly coordinated wage formation process preserves relative wage 
differentials, implying that wages do not reflect emerging differences in relative labor demand and thus contribute relatively little to support ongoing reallocation of labor".

Belgium is indeed characterized by a centralized hierarchical system of collective bargaining for wages, which takes place at the national, industry and firm level; negotiations at each lower level cannot yield less favorable outcomes than the higher level. National agreements set minimum wages. Since 1996, a ceiling for yearly wage increases is also established at the national level every two years, on the basis of gross labor compensations in France, Germany and the Netherlands. This so-called "wage margin" wants to limit wage increases which could harm the competitiveness of Belgian products in the international market. A third nation-wide mechanism affecting wage setting is indexation, which ties gross labor compensations to changes in consumer prices, and establishes a de facto floor for wage increases in the year.

By far the most important wage negotiations in Belgium happen at the industry level, through the about 150 Joint Committees composed by representatives of employees and employers. They establish wage increases at the industry level, as well as pay scales per employee category. Blue and white collar workers usually negotiate in separate Joint Committees. The agreements reached in the Joint Committees bind all companies in the same sector by Royal Decree, making the coverage rate of the agreements approximately $90 \%$ OECD (2004). Finally, 20 to $25 \%$ of private sector workers see their salary determined at the firm level as well (Rusinek and Tojerow 2011; Lopez Novella and Sissoko 2013). The degree of decentralization in wage setting, and the coverage of workers by firm level agreements change significantly with the industry affiliation (Rusinek and Tojerow 2011). Lopez Novella and Sissoko (2013), although not explicitly testing for the impact of firm level bargaining on wages for Belgian workers, provide evidence that when industry-level bargaining is taken into account, the impact of other firm- and employeecharacteristics on wages is reduced, in particular for blue collar workers.

Our analysis investigates the relevance of the mismatch between labor cost and productivity in Belgium, and links it to differences (or lack thereof) in labor market institutions across the regions.

\section{Conceptual framework and literature review}

Average productivity can of course differ across regions: Konings and Torfs (2011), for instance, show that agglomeration economies can explain important differences in productivity. Since economic activity is more concentrated in Flanders than in Wallonia for instance, it is likely that agglomeration economies (such as input-output linkages, knowledge spillovers and labor market pooling) are more important in Flanders than in Wallonia, resulting in higher productivity in the former. Similarly, Epifani and Gancia (2005) create and simulate a model of regional unemployment with migration and trade, where regional differences in productivity coexist with regional unemployment differentials due to agglomeration forces and congestion effects in utility.

In order to match these regional differences in labor productivity, wages should also adjust at a regional level to obtain full employment. This is easily explained with the aid of a standard labor market equilibrium graph, such as Figure $1^{2}$.

Figure 1 models the labor market for a sector in two regions with common wage setting. In the case where the marginal product of labor is the same across the two regions 


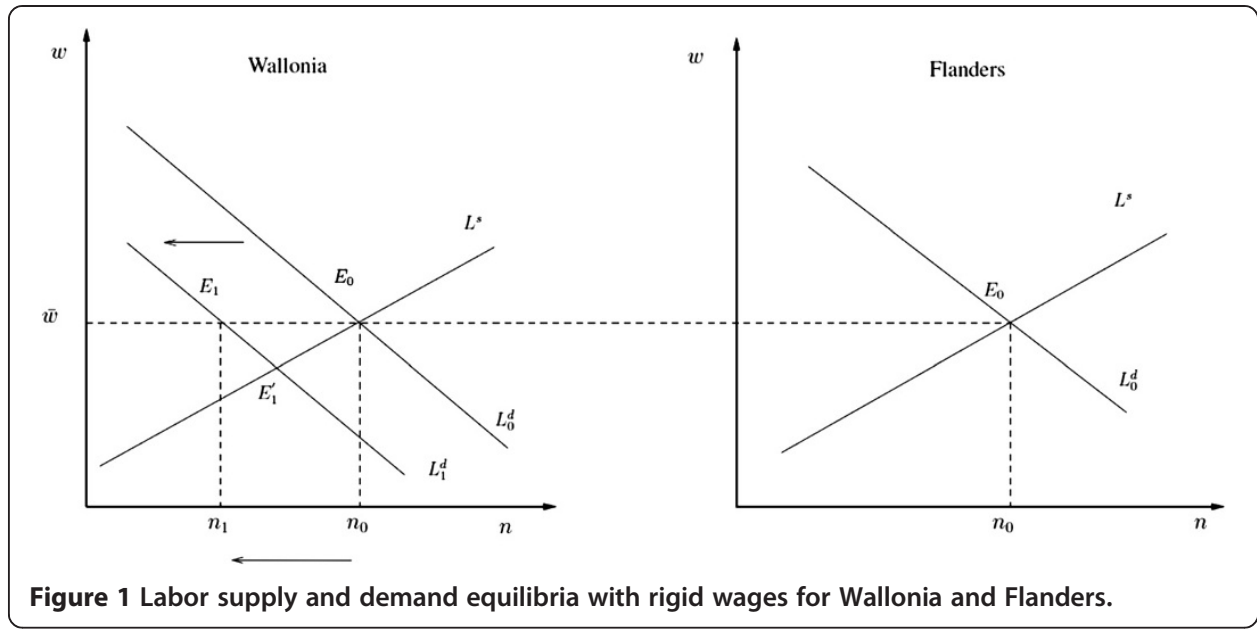

and the wage bargaining process yields the same average wage for a given industry $(\bar{w})$, labor supply and demand meet at equilibrium $E_{0}$. In the presence of agglomeration rents, on the other hand, productivities differ across regions, and so does labor demand. If the marginal product of labor in Wallonia is lower than in Flanders, Wallonia's labor demand schedule $\left(L_{1}^{d}\right)$ is shifted to the right. Reaching full employment (equilibrium $E_{1}^{\prime}$ ) through a decrease in equilibrium wage is impeded by the existence of the nation-wide bargained wage rate $\bar{w}$ for the sector. The labor market in Wallonia reaches the equilibrium $E_{1}$ with unemployment $\left(n_{0}-n_{1}\right)$. The graph suggests that fixing a nation- (sector-) wide wage may be an important factor affecting the reported existence of regional unemployment differentials in Belgium.

A similar argument on the contribution to unemployment of wage setting institutions is proposed by others in the economic literature. It is the case in Pench, Sestito and Frontini (1999), who propose a model where homogeneous labor market in regions with different productivity creates a lower bound wage which is binding for the poorer region. When the same shock hits both a rich and a poor region, employment adjusts differently in the two regions, thus creating unemployment regional differentials. The authors find important regional components of unemployment for Austria, Belgium, Denmark, Germany, Italy and the UK. A similar argument is proposed by Dell'Aringa and Pagani (2005). Davies and Hallet (2001) also argue that regional unemployment differentials are present in European countries due to the failure of wage setting institutions to take into account the productivity level of the least productive region. The gap between wages and labor productivity is one of the determinants of regional unemployment differentials according to Elhorst (2003) as well. In his survey of both theoretical and empirical literature on the existence of regional unemployment differentials, Elhorst (2003) provides a list of thirteen economic phenomena (from employees' and market's characteristics to regional amenities) which have been found relevant for unemployment differentials. Zeilstra and Elhorst (2012) provide evidence that regional unemployment differentials were affected by both regional and national factors in the European Union from 1983 to 1997. Overman and Puga (2002) suggest that regionalization of wage setting should reduce the regional polarization of unemployment in the European Union. More recently, Vamvakidis (2008) exploits a panel of 
regions from 10 European countries and finds that lower coordination of bargaining at the national level can increase regional wage differentials for regions with high productivity differentiation. A distinction between low and high productivity regions is present in Basile and De Benedictis (2007), who explicitly test the impact of regional productivity on regional unemployment, and find it to be negative for low productivity only.

Bande, Fernandez and Montuenga (2008) also argue that the absence of regional wage differentials due to a centralized wage setting can depress labor mobility after a shock, and contribute to the persistence of regional unemployment differentials. On the other hand, however, they provide evidence that regional wage setting may not solve the unemployment differentials: if the most productive region increases salaries due to a positive productivity shock, workers in the poor region may demand comparable wage increases due to fairness considerations, without matching it with a proportional productivity increase. A similar argument for Belgium is proposed by Plasman, Rusinek and Tojerow (2007) and Rusinek and Tojerow (2011): using firm level data they provide evidence that regional wage differentials are already present in the country even when controlling for the composition of firm's labor force, and that these differentials decrease in magnitude when adding a control for labor productivity. What is more, the wage differentials are found to be more positively correlated to productivity differentials when wage negotiations are more decentralized. They therefore conclude that a regionalization of the wage bargaining mechanism may not make wages more sensitive to local specificities.

We contribute to the literature reported above by explicitly investigating the existence of a mismatch between regional premium to wages and productivity in Belgium. We do so by jointly estimating a productivity and a wage equation, similar to Van Biesebroeck (2008).

\section{The empirical framework}

We approach the analysis of the effectiveness of Belgian regional labor markets by estimating a value added per worker function and a wage equation at the firm level; we then assess whether the return to regional localization is different between wages and productivity in each region. The main regressors of interest are dummy variables for the location of the firm in Flanders, Wallonia or the Brussels region. The estimating equations hence read:

$$
\begin{aligned}
& \log \left(\frac{\text { Value Added }}{n}\right)_{i j t}=\alpha_{0}+\alpha_{1} D_{i j t}^{B X}+\alpha_{2} D_{i j t}^{W A}+\alpha_{3} \log (\text { Age })_{i j t}+\alpha_{4} \text { Size }_{i j t}+\varphi_{j}+\theta_{t}+\varepsilon_{i j t} \\
& \log \left(\frac{\text { Wage Bill }}{n}\right)_{i j t}=\gamma_{0}+\gamma_{1} D_{i j t}^{B X}+\gamma_{2} D_{i j t}^{W A}+\gamma_{3} \log (\text { Age })_{i j t}+\gamma_{4} \text { Size } i j t \\
& +\varphi_{j}+\theta_{t}+\eta_{i j t}
\end{aligned}
$$

where the dependent variable of (1) is labor productivity (or value added per employee) of firm " $\mathrm{i}$ " in sector " $\mathrm{j}$ " in year " $\mathrm{t}$ ", while the dependent variable of (2) is average firm wage. $D_{i j t}^{B X}$ and $D_{i j t}^{W A}$ are the dummies for Brussels and Wallonia identifying where the firm is located (the dummy for Flanders is correctly removed to avoid perfect multicollinearity). Age stands for the period past from the year of firm establishment to the 
reporting year, while Size is a proxy for firm's size and will be specified in the estimation as sales; both size and age are important determinants of firms' performance and costs.

Finally, specific sectors and specific years may have an impact on both labor productivity and average wage: to net out our results from such influence, we include industry $\left(\varphi_{\mathrm{j}}\right)$ and year $\left(\theta_{\mathrm{t}}\right)$ fixed effects. $\varepsilon_{\mathrm{ijt}}$ and $\eta_{\mathrm{ijt}}$ are idiosyncratic errors. Contrary to the established literature on wage and productivity premia pioneered by Hellerstein, Neumark and Troske (1999), we cannot control for the characteristics of firm's employees in equations (1) and (2) due to data limitations. The regional distribution of these individual features was found to be relevant for the probability of being unemployed in López-Bazo and Motellón (2013). Similarly we could not find region-specific time series for prices, therefore we do not control for regional price differentials. This may be a concern, as regional differences in prices are reflected in wages and value added (hence productivity): if prices in Brussels (respectively, Wallonia) were consistently higher (respectively, lower) than in Flanders, then failing to control for different regional trends would bias the coefficient on the regional dummy upwards (respectively, downwards). On the other hand, indexation of wages to the nation-wide level of prices should reduce the impact of regional prices on salaries. What is more, biases on productivity and wages induced by the omission of prices from the specification should cancel out when taking the ratio of the two measures as an outcome variable, as in Equation 3 here below.

We first estimate equations (1) and (2) with OLS and clustered errors to account for firm heterogeneity. This provides us with an intuition of the direction in the discrepancy (if any) between labor productivity and average wage due to the regional location of firms. Since there is no variation over time in the location of firms across regions, estimating equations (1)-(2) with OLS exploits between-firm variation in order to identify productivity and wage premia. Our estimators are unbiased if we assume that the establishment of a firm's in a specific region is exogenous to the firm's productivity and average wage; in other words if firms do not self-select into locating in a specific region due to their productivity or average wage. In presence of self-selection, on the contrary, the firm outcomes of interest would determine regional localization (and not the vice versa). Failing to correct for this would bias upwards the coefficient of the dummy for the most productive region in the productivity equation, and bias downwards the coefficient of the dummy for the region with highest labor costs in the wage equation (if one assumes that firms would prefer to locate where the average productivity of their peers is higher and labor costs are lower). We argue that the scope of selfselection in localization is limited in the choice between Flanders and Wallonia or Brussels in light of the existence of the linguistic and cultural barriers. This happens for workers flows, for instance, as empirically proved by Persyn and Torfs (2012), who find regional borders effects on the commuting flows across Belgian regions. The intuition is similar to Lazear (1999), who argues that success in the labor market increases with the capability of speaking the language, which in turn enhances social interaction and information gathering.

Including a control for the age of the firm should also limit the bias due to endogeneity. If firms located in the most productive region, the benefits from the location should be especially important in the early life of the company, soon after its establishment. In 
our main specification, however, we control for firm's age, which should reduce the bias of the coefficient of the regional dummy. What is more, in a robustness check, we estimate our empirical framework distinguishing between younger and older firms. The upward bias in the coefficients for regional dummies should be lower for older firms, were self-selection a concern. While we do find the elasticities of productivity and wages to location to be greater in magnitude for younger firms than older firms for Brussels in particular, this difference is not statistically significant in the case of the wage-productivity gap for Wallonia. What is more, even when the elasticities are significantly different between specifications, the sign of the coefficient is the same as in the main specification obtained pooling over all firm ages, thus implying that the direction of our baseline results is robust to endogeneity.

Simple OLS, however, does not permit to explicitly test whether the coefficient of the regional dummy is equal between equation (1) and (2), as the two equations are estimated on different samples and for different outcome variables. The literature has hence reverted to the joint estimation of productivity and wage equations, either by transforming the data as in the seminal paper by Hellerstein, Neumark and Troske (1999), or by using seemingly unrelated regressions (SUR), as in Van Biesebroeck (2008, 2011). This econometric technique helps in estimating systems of two or more equations representing relationships which are linked one with each other, i.e. when the errors are correlated across equations in the system (Zellner 1962, Fiebig 2001). By simultaneously estimating the two (or more) equations, SUR consistently estimates the errors' covariance matrix, thus permitting cross-equation comparison of coefficients. As a consequence, we also estimate the productivity and wage regressions simultaneously with SUR, which yields a Feasible GLS estimator, and test the hypothesis that no mismatch is present, i.e. $\alpha_{1}=\gamma_{1}$ and $\alpha_{2}=\gamma_{2}$.

The innovative paper by Van Ours and Stoeldraijer (2011) provided a further method to test the relative magnitude of wage and productivity premium in a statistically significant way. They add a third estimating equation, where the dependent variable is the difference of the dependent variables in equations (1) and (2):

$$
\log \left(\frac{\text { Value Added }}{\text { Wage Bill }}\right)_{i j t}=\pi_{0}+\pi_{1} D_{i j t}^{B X}+\pi_{2} D_{i j t}^{W A}+\pi_{3} \log (\text { Age })_{i j t}+\pi_{4} \text { Size }_{i j t}+\varphi_{j}+\theta_{t}+\epsilon_{i j t}
$$

We then restrict the sample to the same number of observations across the three estimating equations, so that $\pi_{1}=\alpha_{1}-\gamma_{1}$ and $\pi_{2}=\alpha_{2}-\gamma_{2}$. If $\pi_{1}$ and $\pi_{2}$ resulted significantly equal to zero, the hypothesis of equality of coefficients across value added and wage cost equations would be validated. This methodology for testing the significance of the wage-productivity gap at the firm level was also adopted by Cataldi, Kampelmann and Rycx (2011), Garnero and Rycx (2013), and Vandenberghe (2013) ${ }^{3}$, although without applying it to a regional context. What is more, equation (3) can yield interesting evidence by itself, as its dependent variable, i.e. the value added produced with one unit of salary, can be interpreted as competitiveness. This measure is also adopted as a proxy for internal competitiveness by the European Commission ${ }^{4}$.

We run the three mentioned estimation techniques (OLS, OLS on the restricted sample, SUR) using different specifications of the outcome variables. In particular, the number of full time equivalent employees $(n)$ in equations (1)-(3) is substituted by the 
average number of employees working for the firm, and by the number of hours worked by full time equivalent employees. The latter is a common feature in the labor economics literature, where hours worked are considered a more precise account of the labor input contribution to production. A fourth specification includes workers' benefits and compensations into the wage bill, which can also be considered part of labor costs.

\section{Data and descriptive statistics}

We work on firm level data obtained from the Bureau Van Dijk product for Belgium (Belfirst). The dataset covers the population of Belgian firms and the reporting quality is high. We exploit both accounting data (turnover, value added, cost of intermediate inputs) and social balance sheet information (number of full, full time equivalent and part time employees, wage bill and compensations by category, hours worked). We retrieve data from all operating firms in the years 2005-2012. After some cleaning, we are left with 518,758 firm (or 430,544 firms on average per year), 59\% of which was located in Flanders, 24\% in Wallonia and 17\% in Brussels (ref. Table 1).

Table 2 contains summary statistics for the sample which will be used to estimate our regressions, by region of firm localization. Labor productivity is defined as value added per full time equivalent employee, while wages are computed by dividing the firm-level total cost of full time equivalent employees by the number of such workers. Labor costs are reported before labor contribution reductions and they do not include benefits and compensations. In a robustness check, we report estimation results inclusive of such benefits, but this does not change the conclusions of our analysis. The ratio of labor productivity and unit wages yields value added per average wage, and it represents our measure of competitiveness. Capital intensity is defined as the sum of tangible and intangible fixed assets, over the number of full time equivalent employees. All quantities, as well as the regional affiliation of companies, are defined at the firm level, due to data limitations which do not permit to distinguish different establishments within the same firm. This may be problematic if our sample contains companies filing single accounting information for multiple plants which are located in different regions, and in particular for productivity, which is more likely to differ between plants of the same firm than wages. Were this the case, our statistics and estimation results would be biased upwards for the region where the headquarter is established, which is likely to be the case especially for the region of Brussels $^{5}$. The regional dummies are defined according to the NUTS1 classification ${ }^{6}$.

From a first glance to the data it emerges that Flanders has a higher value added per average wage than Wallonia and Brussels ${ }^{7}$. This is due mainly to the better performance of Flanders in terms of average labor productivity (i.e. value added per worker), which is coherent with previous evidence (Konings and Marcolin 2011) ${ }^{8}$, despite the high wages (higher than in the other regions).

Table 1 Size of the sample by region

\begin{tabular}{cccc}
\hline & Number of firms & \% Number of firms & Number of observations \\
\hline $\boldsymbol{F L}$ & 305,534 & 58.9 & $2,020,564$ \\
$\boldsymbol{W} \boldsymbol{A}$ & 126,528 & 24.39 & 839,687 \\
$\boldsymbol{B X}$ & 86,696 & 16.71 & 584,104 \\
Total & 518,758 & & $3,444,355$ \\
\hline
\end{tabular}

Notes: "Number of firms" is to be intended as the number of firms appearing at least once in the datasets. 
Table 2 Variables of interest, averages over all years (2005-2012)

\begin{tabular}{|c|c|c|c|c|c|c|}
\hline & & Count & Mean & sd & Min & Max \\
\hline \multirow[t]{7}{*}{ Flanders } & Value added & 259532 & 1117.04 & 10660.60 & 0 & 1664001 \\
\hline & Wage bill & 259532 & 681.50 & 5567.46 & 1 & 570587 \\
\hline & Number of employees & 259532 & 14.69 & 116.66 & 1 & 13353 \\
\hline & Labor productivity & 259532 & 81.94 & 59.56 & 0 & 475.29 \\
\hline & Average wage & 259532 & 37.75 & 16.10 & 0 & 106.35 \\
\hline & Competitiveness & 259532 & 2.39 & 1.95 & 0 & 17 \\
\hline & Capital intensity & 259532 & 106.14 & 309.19 & 0 & 27180 \\
\hline \multirow[t]{7}{*}{ Wallonia } & Value added & 109574 & 876.74 & 12927.49 & 0 & 2822272 \\
\hline & Wage bill & 109574 & 536.85 & 4430.72 & 1 & 595290 \\
\hline & Number of employees & 109574 & 12.67 & 84.65 & 1 & 11125 \\
\hline & Labor productivity & 109574 & 66.65 & 49.56 & 0 & 475 \\
\hline & Average wage & 109574 & 32.47 & 14.75 & 0 & 106.27 \\
\hline & Competitiveness & 109574 & 2.29 & 1.89 & 0 & 17 \\
\hline & Capital intensity & 109574 & 82.42 & 244.62 & 0 & 13256 \\
\hline \multirow[t]{7}{*}{ Brussels } & Value added & 48426 & 2658.26 & 37493.63 & 0 & 2766212 \\
\hline & Wage bill & 48426 & 1615.62 & 21974.47 & 1 & 1394097 \\
\hline & Number of employees & 48426 & 32.08 & 471.72 & 1 & 34565 \\
\hline & Labor productivity & 48426 & 71.52 & 59.67 & 0 & 475.38 \\
\hline & Average wage & 48426 & 37.13 & 19.07 & 0 & 106.36 \\
\hline & Competitiveness & 48426 & 2.13 & 1.87 & 0 & 17 \\
\hline & Capital intensity & 48426 & 84.54 & 334.78 & 0 & 13193 \\
\hline \multirow[t]{7}{*}{ Total } & Value added & 417532 & 1232.73 & 16667.86 & 0 & 2822272 \\
\hline & Wage bill & 417532 & 751.88 & 8973.54 & 1 & 1394097 \\
\hline & Number of employees & 417532 & 16.17 & 190.22 & 1 & 34565 \\
\hline & Labor productivity & 417532 & 76.72 & 57.53 & 0 & 475.38 \\
\hline & Average wage & 417532 & 36.30 & 16.30 & 0 & 106.36 \\
\hline & Competitiveness & 417532 & 2.34 & 1.93 & 0 & 17 \\
\hline & Capital intensity & 417532 & 97.42 & 296.94 & 0 & 27180 \\
\hline
\end{tabular}

(All variables are expressed in '000 EUR, except for number of employees).

The described sample is reported in Figures 2, 3, 4, and 5 as well, where each graph displays the trend in average labor productivity, average wage and their ratio, as well as the number of hours worked by full time equivalent employees. Brussels and Wallonia score worse than Flanders in productivity over all the years in the sample, while Brussels average wages are comparable to the Flemish ones. This is reflected in a striking negative performance of Brussels relative to the other regions in the sample (ref. Figure 4). On the other hand, in the latest years the trends in labor productivity seem to suggest a slowing down in the rate of growth for Flanders, thus permitting Wallonia and Brussels to catch up with the region in terms of value added per average wage. The slope of the schedule for the number of hours worked does not seem to differ in an important fashion between regions, but firms in Brussels report a significantly higher number of hours worked than in the other regions, on average over the whole sample. We now turn to the econometric analysis to estimate which of these descriptive facts are confirmed by a more rigorous assessment of the data. 


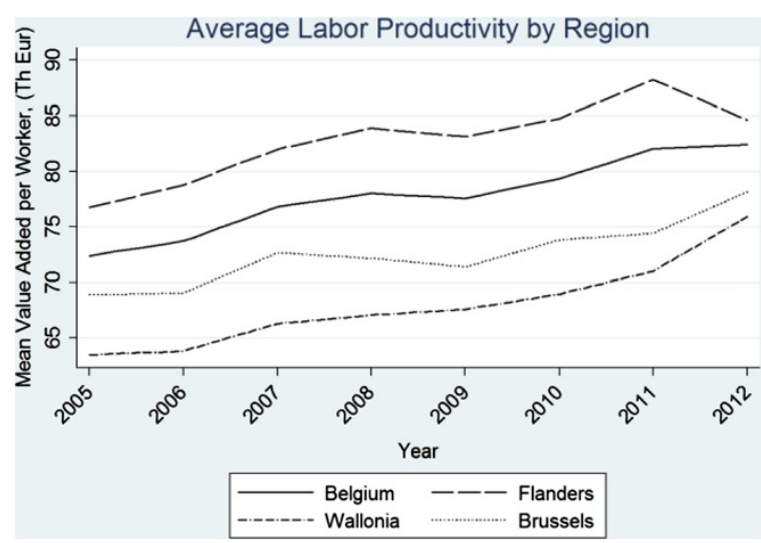

Figure 2 Trends in average labor productivity (2005-2012).

\section{Regression analysis}

Table 3 reports the results of the estimated regressions where information on full time equivalent employees has been exploited. $B x$ and $W a$ represent the dummies for the location of a firm in the Brussels and Wallonia region, respectively. All results for the regional dummies, as a consequence, need to be interpreted in relative terms to Flanders. Size2-Size4 are dummies for the size of the firm, respectively for small firms (i.e. with more than 10 employees and less than 51), medium (more than 50 and less than 251) and big (more than 250) firms. The excluded category are then micro firms (10 employees or less), hence all results should be interpreted in relative terms to this category ${ }^{9}$. The dependent variable for each model is specified in the header of the columns. Results are reported for the three estimation techniques presented in the previous paragraph: OLS with clustered errors, OLS with clustered errors where the sample is restricted to have the same number of observations for the three different outcome variables, and seemingly unrelated regressions. All estimations include year and industry fixed effects, so as to net the coefficients of interest from time trends and industry specificities. We therefore implicitly compare firms which have identical features except for their location.

The three different econometric specifications yield coherent results ${ }^{10}$. All coefficients are highly significant across the three specifications. The last two rows of the

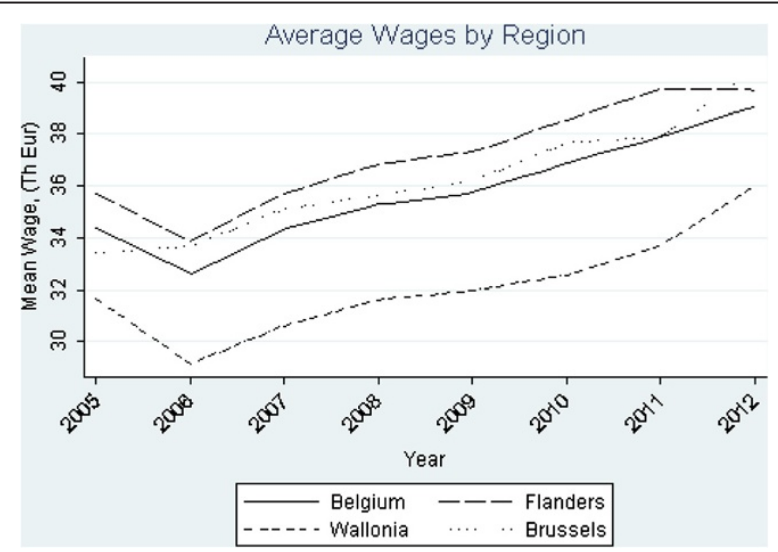

Figure 3 Trends in average wages (2005-2012). 


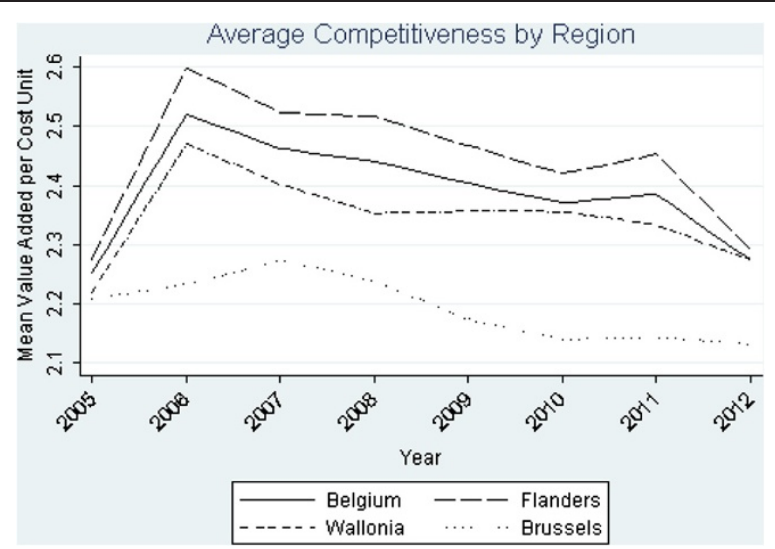

Figure 4 Trends in average competitiveness (2005-2012).

table report the signs and magnitudes for the elasticities obtained from the regional dummies. $\mathrm{EL}(\mathrm{Bx})$ (respectively, $\mathrm{EL}(\mathrm{Wa})$ ) is the computed elasticity of the outcome variable to being located in Brussels (resp. Wallonia) rather than Flanders. Halvorsen and Palmquist (1980) proved that these elasticities need to be computed from the estimated coefficients according to the following transformation:

$$
E L(X)=e^{\beta_{X}}-1
$$

where $\left(\beta_{X}\right)$ is the estimated coefficient for the regional dummy $X=\{B x ; W \alpha\}$. Our regressions indicate that, everything else held constant, firms located in Brussels and Wallonia rather than Flanders benefit of a discount in average wage cost of approximately $5 \%$ and $13.5 \%$ respectively. On the other hand, they also suffer from a substantial disadvantage in labor productivity ranging from $16 \%$ to $17 \%$ for Brussels and Wallonia. As a consequence, the wage-productivity gap of these regions with respect to Flanders is significant and equal to $11 \%$ for Brussels and $4.2 \%$ for Wallonia for 2005-12, conditional on our other controls. This is equivalent to say that the gap between the wage and productivity premium associated with firm's location is almost three times as big in Brussels than in Wallonia.

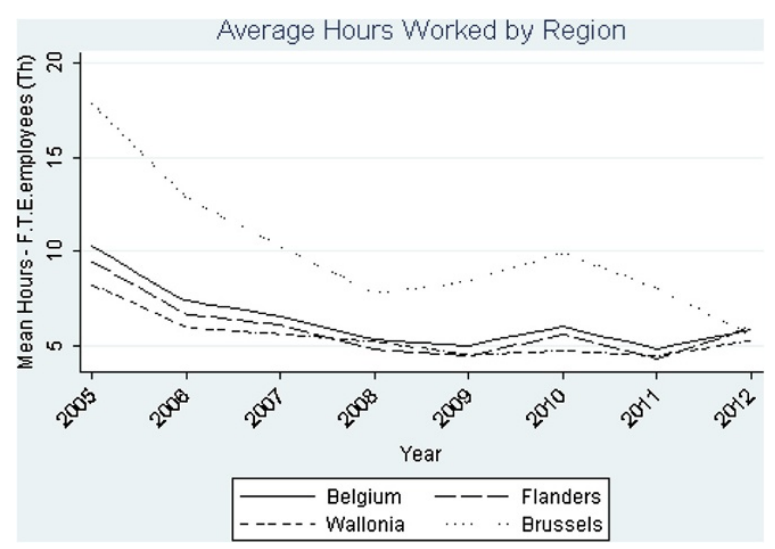

Figure 5 Trends in average hours worked (2005-2012). 
Table 3 Regressions results for full time equivalent employees 2005-2012

\begin{tabular}{|c|c|c|c|c|c|c|c|c|c|}
\hline \multirow[b]{3}{*}{ VARIABLES } & \multicolumn{3}{|c|}{ OLS } & \multicolumn{3}{|c|}{ OLS(re) } & \multicolumn{3}{|c|}{ SUR } \\
\hline & (a) & (b) & (c) & (d) & (e) & (f) & (g) & (h) & (i) \\
\hline & LogW & LogLP & LogGAP & LogW & LogLP & LogGAP & LogW & LogLP & LogGAP \\
\hline \multirow[t]{2}{*}{$B x$} & $-0.0521^{* * *}$ & $-0.172^{* * *}$ & $-0.117^{* * *}$ & $-0.0518^{* * *}$ & $-0.168^{* * *}$ & $-0.117^{* * *}$ & $-0.0518^{* * *}$ & $-0.168^{* * *}$ & $-0.117^{* * *}$ \\
\hline & $(0.00381)$ & (0.00499) & $(0.00416)$ & $(0.00381)$ & $(0.00500)$ & $(0.00416)$ & $(0.00262)$ & $(0.00305)$ & $(0.00231)$ \\
\hline \multirow[t]{2}{*}{ Wa } & $-0.145^{* * *}$ & $-0.189^{* * *}$ & $-0.0431^{* * *}$ & $-0.145^{* * *}$ & $-0.188^{* * *}$ & $-0.0431^{* * *}$ & $-0.145^{* * *}$ & $-0.188^{* * *}$ & $-0.0431^{* * *}$ \\
\hline & $(0.00253)$ & (0.00330) & (0.00288) & $(0.00253)$ & $(0.00330)$ & (0.00288) & $(0.00165)$ & $(0.00238)$ & $(0.00216)$ \\
\hline \multirow[t]{2}{*}{ Logage } & $0.0399^{* * *}$ & $0.0453^{* * *}$ & $0.00509^{* * *}$ & $0.0396^{* * *}$ & $0.0447^{* * *}$ & $0.00509^{* * *}$ & $0.0396^{* * *}$ & $0.0447^{* * *}$ & $0.00509^{* * *}$ \\
\hline & $(0.00112)$ & $(0.00148)$ & $(0.00131)$ & $(0.00112)$ & $(0.00148)$ & $(0.00131)$ & $(0.000943)$ & (0.00128) & $(0.00120)$ \\
\hline \multirow[t]{2}{*}{ Size2 } & $0.208^{* * *}$ & $-0.0692^{* * *}$ & $-0.278^{* * *}$ & $0.208^{* * *}$ & $-0.0702^{* * *}$ & $-0.278^{* * *}$ & $0.208^{* * *}$ & $-0.0702^{* * *}$ & $-0.278^{* * *}$ \\
\hline & $(0.00245)$ & $(0.00351)$ & $(0.00283)$ & $(0.00245)$ & $(0.00351)$ & $(0.00283)$ & $(0.00162)$ & $(0.00235)$ & $(0.00197)$ \\
\hline \multirow[t]{2}{*}{ Size3 } & $0.305^{* * *}$ & $-0.0182^{* *}$ & $-0.323^{* * *}$ & $0.305^{* * *}$ & $-0.0177^{* *}$ & $-0.323^{* * *}$ & $0.305^{* * *}$ & $-0.0177^{* * *}$ & $-0.323^{* * *}$ \\
\hline & $(0.00482)$ & (0.00708) & $(0.00521)$ & $(0.00480)$ & $(0.00706)$ & $(0.00521)$ & (0.00308) & $(0.00391)$ & $(0.00346)$ \\
\hline \multirow[t]{2}{*}{ Size4 } & $0.369^{* * *}$ & 0.0124 & $-0.352^{* * *}$ & $0.370^{* * *}$ & 0.0182 & $-0.352^{* * *}$ & $0.370^{* * *}$ & 0.0182 & $-0.352^{* * *}$ \\
\hline & $(0.0111)$ & $(0.0177)$ & $(0.0122)$ & (0.0109) & $(0.0172)$ & $(0.0122)$ & (0.00809) & $(0.0116)$ & $(0.00858)$ \\
\hline Year FE & Yes & Yes & Yes & Yes & Yes & Yes & Yes & Yes & Yes \\
\hline Industry FE & Yes & Yes & Yes & Yes & Yes & Yes & Yes & Yes & Yes \\
\hline Obs & 410702 & 414670 & 410324 & 410324 & 410324 & 410324 & 410324 & 410324 & 410324 \\
\hline $\mathrm{EL}(\mathrm{Bx})$ & -0.051 & -0.158 & -0.110 & -0.050 & -0.155 & -0.110 & -0.050 & -0.155 & -0.110 \\
\hline EL(Wa) & -0.135 & -0.173 & -0.042 & -0.135 & -0.171 & -0.042 & -0.135 & -0.171 & -0.042 \\
\hline
\end{tabular}

Robust standard errors in parentheses for OLS and OLS(re). Bootstrapped standard errors for SUR.

${ }^{* * *} p<0.01,{ }^{* *} p<0.05,{ }^{*} p<0.1$. 
Interpreting the relative magnitude of coefficients of regional dummies across different models is possible thanks to the seemingly unrelated regressions (Zellner 1962). We hence tested for the equality of the coefficient of the dummy for Brussels (respectively, Wallonia) across the productivity and wage equations. The null hypothesis is always strongly rejected at $1 \%$ value $^{11}$. Standard errors are bootstrapped to take into account heterogeneity in the errors.

Finally, Table 3 highlights that a 1\% increase in the age of the firm improves the firm's ratio of value added to total labor costs by $0.5 \%$. This happens thanks to a productivity premium to age which exceeds the cost burden of being relatively established firms in the market. In other words, the longer a firm has been operating, the higher its average wage bill will be (due, for instance, to the presence of internal labor markets), but also its productivity. The reverse is true for size: being bigger corporations can impose a gap between labor costs and productivity by $24 \%$ to $29 \%$, depending on the size category ${ }^{12}$.

A proxy for firm's capital intensity is omitted, in light of its high correlation with firm's age and size. If it were included we would expect a positive sign for its coefficient, due to the positive correlation between capital intensity and the outcome variables. The correlation of capital intensity with the regional dummies, on the other hand, is almost zero on average over the sample years, hence the magnitude of the estimated regional fixed effects should be unbiased ${ }^{13,14}$. We check the validity of our results by estimating the same models as in $\mathrm{Eq}(1)$-(3) but exploiting different information set (Table 4). Columns $a 1-a 3$ are estimated using the firm's average number of employees rather than the full time equivalent number of them, and the average cost of employees. Columns $b 1-b 3$ deflates both value added and total wage bill by the number of hours worked by full time equivalent employees rather than the number of employees. Finally, columns $c 1-c 3$ are estimated adding workers' benefits and compensations to the wage bill, but once again using the number of full time equivalent employees to generate average wage and labor productivity. To be synthetic, we present here only results obtained from the complete sample (OLS) and from SUR on the restricted sample ${ }^{15}$.

Results are coherent with the estimation using full time equivalent employees: Brussels and Wallonia enjoy a discount in average wage and hourly labor costs with respect to Flanders of approximately 5\% for Brussels and 12 to $13 \%$ for Wallonia, conditional on all other firm characteristics we control for. However, the labor productivity disadvantage is lower than the cost advantage for the regions, suggesting that workers in both regions relative to Flanders are overpaid. The wage-productivity gap is hence positive ${ }^{16}$ and reaches 4 to $7 \%$ for Wallonia relative to Flanders, and 11 to 15\% for Brussels. Signs are mostly coherent with previous specifications also for the age and size of the firm. An increase in both parameters yields an increase in the average wage cost for the firm; age, however, also raises labor productivity, contrary to size. Consequently, the productivitywage gap is generally positively affected by an increase in firm's age (except when we run our estimation using worked hours) and negatively affected by an increase in firm's size.

Table 5 presents a second robustness check, where we investigate the differences in the regional elasticities depending on the age of the firm. We exploited the year of incorporation to construct a dummy variable ("Old") taking value 1 for all observations where the firm is at least 10 years old at the time of observation. We then interact this dummy with the main regressors of interest ( $\mathrm{Bx}$ and Wa). A precise comparison with the baseline results in previous tables is impossible, as the control for the logarithm of 
Table 4 Robustness checks for outcome variables in levels 2005-2012

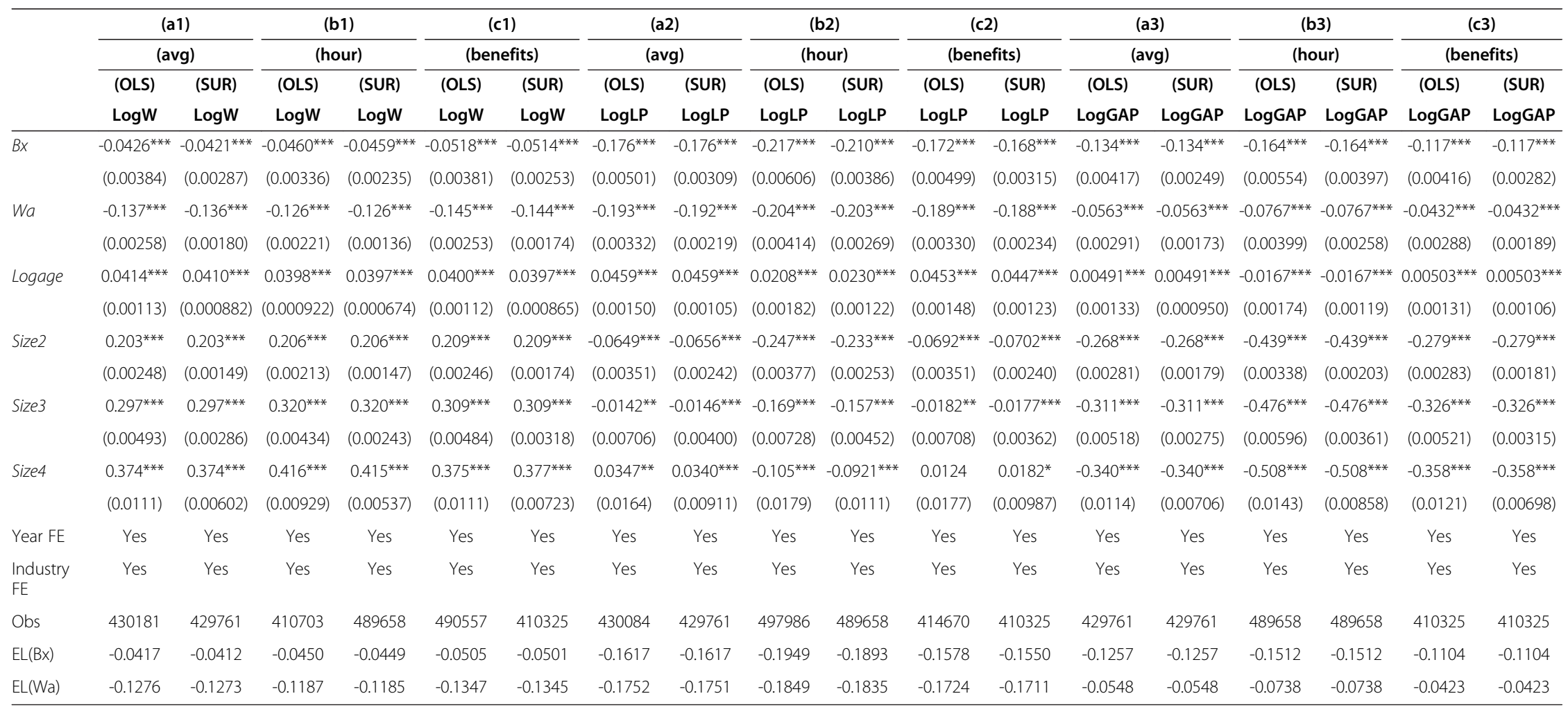

Notes:
Robust standard errors in parentheses for OLS. Bootstrapped standard errors for SUR. (avg) implies that the estimations use information for the "average" employee. (hour) implies that the estimations use hours worked instead of number of employees. (benefits) implies that the estimations include worker's benefits in the labor cost.

${ }^{* * *} p<0.01,{ }^{* *} p<0.05,{ }^{*} p<0.1$. 
Table 5 Robustness checks for older vs younger firms

\begin{tabular}{|c|c|c|c|c|c|c|}
\hline \multirow[b]{3}{*}{ VARIABLES } & \multicolumn{3}{|c|}{ OLS } & \multicolumn{3}{|c|}{ OLS(re) } \\
\hline & (a) & (b) & (c) & (d) & (e) & (f) \\
\hline & $\log W$ & LogLP & LogGAP & LogW & LogLP & LogGAP \\
\hline \multirow[t]{2}{*}{$B x$} & $-0.0961^{* * *}$ & $-0.246^{* * *}$ & $-0.144^{* * *}$ & $-0.0955^{* * *}$ & $-0.240^{* * *}$ & $-0.144^{* * *}$ \\
\hline & $(0.00607)$ & $(0.00755)$ & $(0.00642)$ & $(0.00606)$ & (0.00759) & $(0.00642)$ \\
\hline \multirow[t]{2}{*}{ Wa } & $-0.174^{* * *}$ & $-0.221^{* * *}$ & $-0.0449^{* * *}$ & $-0.174^{* * *}$ & $-0.218^{* * *}$ & $-0.0449^{* * *}$ \\
\hline & $(0.00406)$ & $(0.00502)$ & $(0.00448)$ & $(0.00405)$ & $(0.00503)$ & $(0.00448)$ \\
\hline \multirow[t]{2}{*}{$B x^{*} O / d$} & $0.0703^{* * *}$ & $0.117^{* * *}$ & $0.0415^{* * *}$ & $0.0699^{* * *}$ & $0.111^{* * *}$ & $0.0415^{* * *}$ \\
\hline & $(0.00734)$ & $(0.00948)$ & $(0.00800)$ & $(0.00733)$ & $(0.00952)$ & $(0.00800)$ \\
\hline \multirow[t]{2}{*}{ Wa*Old } & $0.0440^{* * *}$ & $0.0432^{* * *}$ & -0.00127 & $0.0435^{* * *}$ & $0.0423^{* * *}$ & -0.00127 \\
\hline & (0.00493) & $(0.00628)$ & $(0.00555)$ & $(0.00493)$ & $(0.00629)$ & $(0.00555)$ \\
\hline \multirow[t]{2}{*}{ Old } & $0.0590^{* * *}$ & $0.0460^{* * *}$ & $-0.0124^{* * *}$ & $0.0586^{* * *}$ & $0.0463^{* * *}$ & $-0.0124^{* * *}$ \\
\hline & $(0.00263)$ & $(0.00354)$ & $(0.00319)$ & $(0.00263)$ & $(0.00354)$ & $(0.00319)$ \\
\hline \multirow[t]{2}{*}{ Size2 } & $0.215^{* * *}$ & $-0.0561^{* * *}$ & $-0.272^{* * *}$ & $0.214^{* * *}$ & $-0.0574^{* * *}$ & $-0.272^{* * *}$ \\
\hline & $(0.00242)$ & (0.00349) & $(0.00280)$ & $(0.00242)$ & $(0.00348)$ & $(0.00280)$ \\
\hline \multirow[t]{2}{*}{ Size3 } & $0.317^{* * *}$ & 0.00275 & $-0.314^{* * *}$ & $0.317^{* * *}$ & 0.00280 & $-0.314^{* * *}$ \\
\hline & $(0.00479)$ & $(0.00703)$ & $(0.00515)$ & $(0.00477)$ & $(0.00700)$ & $(0.00515)$ \\
\hline \multirow[t]{2}{*}{ Size4 } & $0.383^{* * *}$ & $0.0368^{* *}$ & $-0.343^{* * *}$ & $0.385^{* * *}$ & $0.0422^{* *}$ & $-0.343^{* * *}$ \\
\hline & $(0.0110)$ & $(0.0175)$ & $(0.0121)$ & $(0.0108)$ & $(0.0170)$ & $(0.0121)$ \\
\hline Year FE & Yes & Yes & Yes & Yes & Yes & Yes \\
\hline Industry FE & Yes & Yes & Yes & Yes & Yes & Yes \\
\hline Observations & 417637 & 421704 & 417234 & 417234 & 417234 & 417234 \\
\hline EL(Bx, Young) & -0.092 & -0.218 & -0.134 & -0.091 & -0.213 & -0.134 \\
\hline EL(Wa, Young) & -0.160 & -0.198 & -0.044 & -0.159 & -0.196 & -0.044 \\
\hline $\mathrm{EL}(\mathrm{Bx}, \mathrm{Old})$ & -0.025 & -0.121 & -0.097 & -0.025 & -0.120 & -0.097 \\
\hline EL(Wa, Old) & -0.122 & -0.163 & -0.045 & -0.122 & -0.162 & -0.045 \\
\hline
\end{tabular}

Notes:

Robust standard errors in parentheses. OLS(re) is the specification where the sample is restricted to the same number of observations per each outcome variable (columns (d)-(f)).

(Old) is a dummy equal to 1 when the firm has been established at least 10 years before.

$\mathrm{EL}(\mathrm{Bx}$, Young) is the elasticity of the outcome variable to the regional location for a "young" firm.

${ }^{* * *} \mathrm{p}<0.01,{ }^{* *} \mathrm{p}<0.05,{ }^{*} \mathrm{p}<0.1$.

firm's age had to be dropped, but Table 5 still provides useful insights. The signs of the elasticities for both young and old firms stay the same as in the pooled sample ${ }^{17}$. The cost advantage enjoyed by firms in Brussels and in particular in Wallonia relative to firms in Flanders applies to both young and old establishments. The elasticities in the wage equation are significantly higher for young firms than older firms, and in particular for firms located in Brussels. The productivity disadvantage of non-Flemish firms is also higher for younger firms than older ones, coherently with the positive correlation between age and productivity we estimated in the previous specifications. The average old firm in Brussels, on the other hand, performs better than the counterpart in Wallonia (relative to a firm in Flanders), which is not the case for a younger firm. The gap between the wage and productivity premium associated with firm's location is bigger in Brussels than in Wallonia, but distinguishing this effect between young and old firms is not possible, since the coefficient on the Wallonia regional dummy in the gap equation is not significantly different for older and younger firms. The impact of being located in Brussels on the productivity-wage gap is greater for younger firms. 


\section{Dynamics}

The picture of relative performance of Belgian regions partially changes when taking into considerations the growth rate of labor productivity and average wage. We explore this venue to conform to the current policy debate, which seems to prefer comparisons across administrative units based on the rate of growth more than on the level of competitiveness. Higher productivity growth is indeed generally associated to a higher economy-wide growth rate, coherently with a neoclassical model of endogenous growth (Lucas 1988, Romer 1994).

We therefore estimate equation (1)-(3) again, where the dependent variables become the year-on-year change in the logarithm of average wage, labor productivity, and their difference. Table 6 shows the results of the estimations for the complete sample and for the sample where the same number of observations is exploited for the three regressions. In the baseline estimation the wage-productivity gap is reduced by the localization of the firm in Brussels but not Wallonia. This result is driven by the rate of productivity growth, which is higher for the former than the latter, and higher than the coefficient for the cost growth equation. This, in turn, is then reflected in a positive and significant coefficient for the dummy of Brussels but not Wallonia. It remains true, however, that being located in either Wallonia or Brussels increases the rate of growth of wages the firm is asked to pay to its workers more than a firm located in Flanders. The coefficients for age and size of the firm, on the other hand, seem to go in the same direction as reported in the estimation in levels: keeping every other firm's characteristics constant, an older or bigger firm displayed a lower yearly rate of growth in the ratio of productivity and wages between 2005 and 2012 .

Table 6 Growth rates for full time equivalent employees 2005-2012

\begin{tabular}{|c|c|c|c|c|c|c|}
\hline \multirow[b]{3}{*}{ VARIABLES } & \multicolumn{3}{|c|}{ OLS } & \multicolumn{3}{|c|}{ OLS (re) } \\
\hline & (a) & (b) & (c) & (d) & (e) & (f) \\
\hline & $\Delta \log W$ & $\Delta$ LogLP & $\Delta$ LogGAP & $\Delta \log W$ & $\Delta$ LogLP & $\Delta$ LogGAP \\
\hline \multirow[t]{2}{*}{$B x$} & $0.00839 * * *$ & $0.0283^{* * *}$ & $0.0191^{* * *}$ & $0.00857^{* * *}$ & $0.0277^{* * *}$ & $0.0191^{* * *}$ \\
\hline & $(0.00195)$ & $(0.00265)$ & $(0.00251)$ & $(0.00195)$ & $(0.00265)$ & $(0.00251)$ \\
\hline \multirow[t]{2}{*}{ Wa } & $0.00989^{* * *}$ & $0.00864^{* * *}$ & -0.00134 & $0.00994^{* * *}$ & $0.00860^{* * *}$ & -0.00134 \\
\hline & (0.00139) & $(0.00173)$ & $(0.00162)$ & (0.00139) & $(0.00174)$ & $(0.00162)$ \\
\hline \multirow[t]{2}{*}{ Logage } & $-0.0106^{* * *}$ & $-0.0468^{* * *}$ & $-0.0357^{* * *}$ & $-0.0105^{* * *}$ & $-0.0462^{* * *}$ & $-0.0357^{* * *}$ \\
\hline & $(0.000818)$ & $(0.00107)$ & $(0.000980)$ & $(0.000817)$ & $(0.00107)$ & $(0.000980)$ \\
\hline \multirow[t]{2}{*}{ Size2 } & $0.0108^{* * *}$ & $-0.0342^{* * *}$ & $-0.0447^{* * *}$ & $0.0107^{* * *}$ & $-0.0339^{* * * *}$ & $-0.0447^{* * *}$ \\
\hline & $(0.00110)$ & $(0.00155)$ & $(0.00142)$ & $(0.00110)$ & $(0.00156)$ & $(0.00142)$ \\
\hline \multirow[t]{2}{*}{ Size3 } & $0.0171^{* * *}$ & $-0.0289^{* * *}$ & $-0.0462^{* * *}$ & $0.0174^{* * *}$ & $-0.0288^{* * *}$ & $-0.0462^{* * *}$ \\
\hline & $(0.00188)$ & $(0.00277)$ & $(0.00248)$ & $(0.00186)$ & $(0.00277)$ & $(0.00248)$ \\
\hline \multirow[t]{2}{*}{ Size4 } & $0.0167^{* * *}$ & $-0.0192^{* * *}$ & $-0.0360^{* * *}$ & $0.0168^{* * *}$ & $-0.0192^{* * *}$ & $-0.0360^{* * *}$ \\
\hline & $(0.00267)$ & $(0.00556)$ & $(0.00525)$ & $(0.00268)$ & $(0.00557)$ & $(0.00525)$ \\
\hline Year FE & Yes & Yes & Yes & Yes & Yes & Yes \\
\hline Industry FE & Yes & Yes & Yes & Yes & Yes & Yes \\
\hline Obs & 228950 & 231117 & 228692 & 228692 & 228692 & 228692 \\
\hline $\mathrm{EL}(\mathrm{Bx})$ & 0.0084 & 0.0287 & 0.0193 & 0.0086 & 0.0281 & 0.0193 \\
\hline EL(Wa) & 0.0099 & 0.0087 & -0.0013 & 0.0100 & 0.0086 & -0.0013 \\
\hline \multicolumn{7}{|l|}{ Notes: } \\
\hline
\end{tabular}


Table 7 Robustness checks for growth rates of outcome variables (2005-2012)

\begin{tabular}{|c|c|c|c|c|c|c|c|c|c|}
\hline & $\begin{array}{l}\text { (a1) } \\
\text { (avg) }\end{array}$ & $\begin{array}{l}\text { (b1) } \\
\text { (hour) }\end{array}$ & $\begin{array}{c}\text { (c1) } \\
\text { (benefits) }\end{array}$ & $\begin{array}{l}\text { (a2) } \\
\text { (avg) }\end{array}$ & $\begin{array}{l}\text { (b2) } \\
\text { (hour) }\end{array}$ & $\begin{array}{c}\text { (c2) } \\
\text { (benefits) }\end{array}$ & $\begin{array}{l}\text { (a3) } \\
\text { (avg) }\end{array}$ & $\begin{array}{c}\text { (b3) } \\
\text { (hour) }\end{array}$ & $\begin{array}{c}\text { (c3) } \\
\text { (benefits) }\end{array}$ \\
\hline VARIABLES & $\Delta \log W$ & $\Delta \mathrm{LogW}$ & $\Delta \log W$ & $\Delta \log \mathrm{LP}$ & $\Delta \log \mathrm{LP}$ & $\Delta \operatorname{LogLP}$ & $\Delta$ LogGAP & $\Delta$ LogGAP & $\Delta$ LogGAP \\
\hline \multirow[t]{2}{*}{$B x$} & $0.00684^{* * *}$ & $0.00351^{*}$ & $0.00875^{* * *}$ & $0.0120^{* * *}$ & $0.0195^{* * *}$ & $0.0277^{* * *}$ & $0.00519^{* *}$ & $0.0160^{* * *}$ & $0.0189^{* * *}$ \\
\hline & $(0.00195)$ & $(0.00201)$ & (0.00196) & $(0.00262)$ & $(0.00371)$ & $(0.00265)$ & $(0.00243)$ & $(0.00341)$ & $(0.00252)$ \\
\hline \multirow[t]{2}{*}{ Wa } & $0.00801^{* * *}$ & $0.0103^{* * *}$ & $0.00997^{* * *}$ & $0.00349^{* *}$ & $0.00592^{* *}$ & $0.00860^{* * *}$ & $-0.00452^{* * *}$ & $-0.00434^{*}$ & -0.00137 \\
\hline & (0.00139) & $(0.00139)$ & (0.00139) & $(0.00172)$ & $(0.00245)$ & $(0.00174)$ & $(0.00160)$ & $(0.00224)$ & $(0.00162)$ \\
\hline \multirow[t]{2}{*}{ Logage } & $-0.0127^{* * *}$ & $0.00399^{* * *}$ & $-0.0105^{* * *}$ & $-0.0450^{* * *}$ & $0.0112^{* * *}$ & $-0.0462^{* * *}$ & $-0.0323^{* * *}$ & $0.00724^{* * *}$ & $-0.0357^{* * *}$ \\
\hline & $(0.000839)$ & $(0.000828)$ & $(0.000818)$ & $(0.00108)$ & $(0.00156)$ & (0.00107) & $(0.000987)$ & $(0.00142)$ & $(0.000980)$ \\
\hline \multirow[t]{2}{*}{ Size2 } & $0.00989^{* * *}$ & $-0.0181^{* * *}$ & $0.0110^{* * *}$ & $-0.0267^{* * *}$ & $-0.0301^{* * *}$ & $-0.0339 * * *$ & $-0.0366^{* * *}$ & $-0.0119^{* * *}$ & $-0.0450^{* * *}$ \\
\hline & $(0.00110)$ & $(0.00121)$ & $(0.00110)$ & $(0.00155)$ & (0.00193) & $(0.00156)$ & (0.00138) & $(0.00169)$ & $(0.00143)$ \\
\hline \multirow[t]{2}{*}{ Size3 } & $0.0169^{* * *}$ & $-0.0250^{* * *}$ & $0.0177^{* * *}$ & $-0.0205^{* * *}$ & $-0.0479 * * *$ & $-0.0288^{* * *}$ & $-0.0373^{* * *}$ & $-0.0229^{* * *}$ & $-0.0465^{* * *}$ \\
\hline & $(0.00172)$ & $(0.00210)$ & $(0.00187)$ & $(0.00271)$ & $(0.00321)$ & $(0.00277)$ & $(0.00245)$ & $(0.00269)$ & $(0.00248)$ \\
\hline \multirow[t]{2}{*}{ Size4 } & $0.0158^{* * *}$ & $-0.0251^{* * *}$ & $0.0176^{* * *}$ & $-0.0149^{* * *}$ & $-0.0432^{* * *}$ & $-0.0192^{* * *}$ & $-0.0306^{* * *}$ & $-0.0181^{* * *}$ & $-0.0368^{* * *}$ \\
\hline & $(0.00440)$ & $(0.00215)$ & $(0.00265)$ & $(0.00550)$ & $(0.00560)$ & $(0.00557)$ & $(0.00402)$ & $(0.00546)$ & $(0.00525)$ \\
\hline Year FE & Yes & Yes & Yes & Yes & Yes & Yes & Yes & Yes & Yes \\
\hline Industry FE & Yes & Yes & Yes & Yes & Yes & Yes & Yes & Yes & Yes \\
\hline Obs & 244884 & 289586 & 228693 & 244884 & 289586 & 228693 & 244884 & 289586 & 228693 \\
\hline $\mathrm{EL}(\mathrm{Bx})$ & 0.0069 & 0.0035 & 0.0088 & 0.0121 & 0.0197 & 0.0281 & 0.0052 & 0.0161 & 0.0191 \\
\hline EL(Wa) & 0.0080 & 0.0103 & 0.0100 & 0.0035 & 0.0059 & 0.0086 & -0.0045 & -0.0043 & -0.0014 \\
\hline
\end{tabular}

Notes:
Robust standard errors in parentheses for OLS. Bootstrapped standard errors for SUR.

(avg) implies that the estimations use information for the "average" employee.

(hour) implies that the estimations use hours worked instead of number of employees.

(benefits) implies that the estimations include worker's benefits in the labor cost.

${ }^{* * *} \mathrm{p}<0.01,{ }^{* *} \mathrm{p}<0.05,{ }^{*} \mathrm{p}<0.1$. 
Our results in the preferred specification therefore suggest that a catching up process may be happening in Belgium in terms of regional productivity. Being located outside Flanders in the sample years guaranteed a higher growth rate of productivity, no matter the cost performance. This translates in a positive coefficient for the productivity-wage gap but only for Brussels, while the coefficient for Wallonia is insignificant due to the important contribution of average wage.

The results are rather robust when turning to different measures of the outcome variables. In Table $7^{18}$, the evidence of the full time equivalent specification is strongly confirmed with respect to Brussels. As far as Wallonia is concerned, on the other hand, the sign of the coefficient for the wage-productivity gap turns from insignificant (for the full time equivalent sample, and here when including workers' benefits (column $c 3$ )) to negative and significant at 1 or $10 \%$ (columns $a 3$ and $b 3$ ). The latter specification, however, reveals that firms located in Wallonia might experience a higher growth of labor costs than in Flanders, which may compensate the higher labor productivity growth, thus cancelling any significant effect on the rate of change in the wage-productivity gap. Evidence of a trend in the reduction of wage-productivity gap for Wallonia relative to Flanders is therefore somewhat mixed, but not for Brussels, where our results portrait a less negative picture of the region's relative standing than suggested by the estimations in levels.

\section{Conclusions}

This study aimed at assessing whether there existed equality in wage and labor productivity premia for firms in Brussels or Wallonia rather than Flanders. Our question stemmed from evidence of academic and policy making nature suggesting that regional labor market institutions influence the matching process of workers with vacancies. We therefore estimated a value-added-per-worker and a wage equation using firm level data for the population of Belgian firms. Our results suggest that even controlling for sector effects we still find important regional differences in wages and productivity, and that in Wallonia and Brussels wages seem to be "too high" compared to labor productivity. This is reflected in a positive and significant wage-productivity gap for firms in Brussels and Wallonia with respect to Flanders. On the other hand, we see that labor productivity fell in 2012 in Flanders more than in Wallonia and Brussels. As a consequence the results of the estimation in growth of labor productivity and average wage highlight that a process of convergence in productivity may be happening for both Brussels and Wallonia, although for Wallonia this is still not enough to reverse the trend in the productivity-wage gap. These results are conditioned by the available data, which do not allow to distinguish between establishments within the same firm, nor to control for the composition of the labor force in human capital.

In absence of cross-region firm productivity convergence, reducing unemployment and hence re-aligning wages with the worker's marginal product of labor requires an intervention on labor market institutions in Belgium. We argue that how our results can be interpreted in the light of the existence of collective agreements which apply to all firms operating within the same sector across all regions in Belgium. One possible field for action would therefore be represented by the wage bargaining process, which could be reformed towards a greater attention to regional specificities in labor productivity. On the other hand, our analysis does not explicitly test the correlation between unemployment and labor-productivity mismatches at the regional level, leaving space for further research on this topic. 


\section{Endnotes}

${ }^{1}$ Ever since 2011, the competence of the regional governments on labor market policies has been strengthened. For instance, regions are now responsible for the interview process which evaluates the unemployed person's job search effort, as well as for the sanctions which may apply as a consequence.

${ }^{2}$ The economic literature, obviously, has moved beyond standard labor market models such as the one presented in Figure 1 (see Manning 2011 for a review of the relevant literature). We recognize that the complexity of the Belgian labor market cannot be synthetized in one such graph, but we believe that Figure 1 provides a simple intuition of the link between the wage-productivity mismatch and unemployment which we are exploring in the following pages.

${ }^{3} \mathrm{An}$ important difference between the current study and the cited research is the choice of determinants which are included in the estimating equations. The quoted papers investigate the impact of workers' characteristics (age, education, gender) or their dispersion on labor productivity and costs, and they do so by exploiting firm level information on the composition of the labor force. We do not have access to such information hence a similar analysis is precluded.

${ }^{4}$ It corresponds to the inverse of real unit labor costs, as in the European Competitiveness Report (2009), European Commission.

${ }^{5}$ In the attempt to reduce this bias in estimation, we ran our analysis also on a subsample of firms which do not report any subsidiary or branch in the database. The main conclusions hold in this case as well, although of course the sample is likely to be biased towards smaller firms (tables available on request).

${ }^{6}$ Accordingly, the NUTS2 region of Halle-Vilvoorde, which is often considered part of the Brussels region due to the strong political and economic links to the capital city, is included in the region of Flanders. In this choice, we are aligned with the statistical offices of major international institutions such as the OECD and Eurostat.

${ }^{7}$ We discuss here descriptive statistics in level to ease the interpretation. The estimations, however, will be carried out in logarithm. Interpreting descriptive statistics in logarithm is in fact not immediate, hence their omission here.

${ }^{8}$ The number of observations per year may differ from Table 1 to Table 2 since some of the firms reported in Table 1 have missing values for some variables of interest. In particular, many firms in the sample do not report any employee, while our analysis focuses on firms with at least one employee.

${ }^{9}$ We also ran regressions using the log of size as a control instead of size dummies. Our conclusions are robust to this specification as well.

${ }^{10}$ The coefficients of OLS(re) and SUR, in particular, are equal by construction, as in both estimations the sample is equally restricted. The computed standard errors, however, are different.

${ }^{11}$ Test statistics and p-values are available upon request.

${ }^{12}$ The exact magnitude of these gains is inferred from the calculation of elasticities such as in the case of regional dummies (not reported).

${ }^{13}$ More precisely the correlations are: $-1.5 \%$ for Brussels, $-2.5 \%$ for Wallonia, $+3 \%$ for Flanders. Even if correlations were higher, however, our current estimates would be underestimating, not overestimating, the size of the regional dummies: as capital intensity is found to be on average higher for firms in Flanders than in the rest of Belgium 
(refer to Table 1), including capital intensity in the estimation would reduce the size of coefficient on the regional dummy for Flanders more than on the ones for Brussels and Wallonia.

${ }^{14}$ Omitting capital from our specification, as a consequence, is not connected to the debate developed by the literature on the determinants of the rate of unemployment. Bande and Karanassou (2009, 2013) empirically estimate a dynamic multi-equation labor market model where they can control for growing variables such as capital accumulation along with usual stationary variables. This feature differentiates the "Chain Reaction Theory" model of unemployment from the literature on the Natural Rate of Unemployment (NRU). As we do not explicitly test an unemployment equation, this paper does not take a stand in the CRT vs NRU debate.

${ }^{15}$ Precise comparison of coefficients in models using averages, hours and benefits is not possible, because the reported regressions are run over different sample sizes, hence each model estimates separate variance/covariance matrixes and standard errors. The same holds for comparison of the columns estimated with OLS and SUR. As mentioned in the main body of the text, comparisons of magnitude in coefficients of labor productivity, average wage and their ratio are on the contrary possible, for the columns estimated with SUR using the same data.

${ }^{16}$ The gap is expressed in terms of productivity over wages, hence the reverse than the wage-productivity gap.

${ }^{17}$ The elasticities for "old" firms at the bottom of the table were correctly computed as a function of the sum of the coefficients on the regional dummy in level and in cross product.

${ }^{18}$ Table 7 , for simplicity, only reports the results using the restricted sample (OLS(re)). The complete set of results is available upon request.

Competing interests

The IZA Journal of European Labor Studies is committed to the IZA Guiding Principles of Research Integrity. The authors declare that they have observed these principles.

\section{Acknowledgements}

We thank the anonymous referee and Cathy Lecocq for helpful comments and suggestions. We are also extremely grateful to the editors of the IZA JOELS for their invitation to submission and their collaboration in the publication process.

Responsible editor: Sara de la Rica

\footnotetext{
Author details

${ }^{1}$ Katholieke Universiteit Leuven, CES \& LICOS, VIVES \& CEPR, Naamsestraat 69, 3000 Leuven, Belgium. Katholieke Universiteit Leuven, CES \& VIVES, Naamsestraat 61, 3000 Leuven, Belgium.
}

Received: 16 September 2013 Accepted: 15 January 2014

Published: 09 Jun 2014

\section{References}

Bande R, Fernández M, Montuenga V (2008) Regional unemployment in Spain: disparities, business cycle and wage setting. Labour Econ 15:885-914

Bande R, Karanassou M (2009) Labour market flexibility and regional unemployment rate dynamics: Spain 1980-1995. Pap Reg Sci 88(1):181-207

Bande R, Karanassou M (2013) The natural rate of unemployment hypothesis and the evolution of regional disparities in Spanish unemployment. Urban Stud 50(10):2044-2062

Basile R, De Benedictis L (2007) Regional Unemployment and Productivity in Europe, Papers in Regional Science

Cataldi A, Kampelmann S, Rycx F (2011) Productivity-wage gaps among age groups: does the ICT environment matter? De Economist 159:193-221

Davies S, Hallet M (2001) Policy Responses to Regional Unemployment: Lessons from Germany. European Commission Economic Papers 161, Spain and Italy

Dell'Aringa C, Pagani L (2005) Regional wage differentials and collective bargaining in Italy. Rivista Internazionale di Scienze Economiche 113:267-287 
Elhorst JP (2003) The mystery of regional unemployment differentials: theoretical and empirical explanations. J Econ Surveys, Wiley Blackwell 17(5):709-748

Epifani P, Gancia GA (2005) Trade, migration and regional unemployment". Reg Sci Urban Econ 25:625-644

European Commission (2009) European Competitiveness Report 2009. The European Commission

Eurostat (2010) Labour market policy - expenditure and participants - Data 2010. Eurostat Statistical Books

12 Fiebig DG (2001) Seemingly Unrelated Regression. In: Baltagi B (ed) A Companion to Theoretical Econometrics. Blackwell Publishers, Oxford, pp 101-121

Garnero A, Rycx F (2013) The heterogeneous effects of workforce diversity on productivity, wages and profits. IZA Discussion Paper No. 7350

Halvorsen R, Palmquist R (1980) The interpretation of dummy variables in semilogarithmic equations. Am Econ Rev 70:474-475

Hellerstein JK, Neumark D, Troske KR (1999) Wages, productivity, and worker characteristics: evidence from plant-level production functions and wage equations. J Labor Econ 17:409-446

Konings J, Marcolin L (2011) The competitiveness of regions: a comparison between Belgian and German regions. Rev Bus Eco Lit LVl:274-288

Konings J, Torfs W (2011) Fiscal Federalism, Tax Competition and Economic Agglomeration. In: Flemish Department of Finance and Budget. Fiscal Federalism in the European Union, Lacier, pp 35-56

Lazear E (1999) Culture and language. J Polit Econ 107:95-126

Lopez NM, Sissoko M (2013) Understanding wage determination in a multi-level bargaining system: a panel data analysis. Empir Econ 44:879-897

López-Bazo E, Motellón E (2013) The regional distribution of unemployment: what do micro data tell us? Papers in regional science, special issue on regional labor markets, pp 384-405

Lucas RE (1988) On the mechanics of economic development. J Monet Econ 22:3-42

Manning A (2011) Imperfect Competition in the Labor Market. In: Aschenfelter O, Card D (ed) Handbook of Labor Economics. Elsevier, pp 973-1041

OECD (2004) OECD Employment Outlook

OECD (2011) OECD Economic Surveys: Belgium

OECD (2013) OECD Economic Surveys: Belgium

Overman H, Puga D (2002) Unemployment clusters across Europe's regions and countries. Econ Policy 17:115-148

Pench L, Sestito P, Frontini E (1999) Some Unpleasant Arithmetic of Regional Unemployment in the EU: are there any Lessons for EMU? European Commission Economic Papers 134

Persyn D, Torfs W (2012) A gravity equation for commuting. Vives:DP33

Plasman R, Rusinek M, Tojerow I (2007) La Régionalisation de la Négotiation Salariale en Belgique : Vraie Nécessité ou Faux Débat? Reflets et perspectives de la vie économique:65-74

Romer PM (1994) The origins of endogenous growth. J Econ Perspect 8:3-22

Rusinek M, Tojerow I (2011) The regional dimension of collective wage bargaining: the case of Belgium. Reg Stud 0:1-17 Vamvakidis A (2008) Regional Wage Differentiation and Wage Bargaining Systems in the EU. IMF WP/08/43

Van Biesebroeck J (2008) Wage and productivity premiums in sub-Saharan Africa. In: The Analysis of Firms and Employees: Quantitative and Qualitative Approaches, NBER Inc, pp 345-371

Van Biesebroeck J (2011) Wages equal productivity: fact or fiction? World Dev 39:1333-1346

Van Ours J, Stoeldraijer L (2011) Age, wage and productivity in dutch manufacturing. De Economist 159:113-137

Vandenberghe V (2013) Are firms willing to employ a greying and feminizing workforce? Labour Econ 22:30-46

Zeilstra AS, Elhorst P (2012) Integrated analysis of regional and national unemployment differentials in the European Union, pp 1-17. Regional Studies (published online)

Zellner A (1962) An efficient method of estimating seemingly unrelated regression equations and tests of aggregation bias. J Am Stat Assoc 57:348-368

Zimmer H (2012) Labour market mismatches. Eco Rev, Nat Bank Belgium 11:55-68

$10.1186 / 2193-9012-3-11$

Cite this article as: Konings and Marcolin: Do wages reflect labor productivity? The case of Belgian regions. IZA Journal of European Labor Studies 2014, 3:11

\section{Submit your manuscript to a SpringerOpen ${ }^{\circ}$ journal and benefit from:}

- Convenient online submission

- Rigorous peer review

- Immediate publication on acceptance

- Open access: articles freely available online

- High visibility within the field

- Retaining the copyright to your article

Submit your next manuscript at $\boldsymbol{~ s p r i n g e r o p e n . c o m ~}$ 